Aleksandra Bańkowska, Agnieszka Haska

\title{
Powojenni lokatorzy budynku przy ul. Tłomackie 5
}

Budynek Głównej Biblioteki Judaistycznej został podpalony w maju 1943 r. podczas wysadzania Wielkiej Synagogi, ale jego mury przetrwały wojnę. W metryczce budynku (noszącego wówczas adres Tłomackie 5) podczas inwentaryzacji przeprowadzonej przez Biuro Odbudowy Stolicy w końcu lutego 1945 r. zapisano: „Budynek nowy, murowany, stropy ogniotrwałe, ogrzewanie centralne, 4 kondygnacje. Elewacja frontowa wypalona, stropy nienaruszone, słupy konstrukcyjne $\mathrm{w}$ stanie dobrym. Sutereny mieszkalne nieuszkodzone. Elewacja boczna: I piętro częściowo wypalone, II i III piętro częściowo wypalone. Dach lekko uszkodzony. [...] Wniosek: do odbudowy się nadaje"1. Na tle zniszczonej lewobrzeżnej Warszawy częściowo uszkodzony budynek był luksusem, nic zatem dziwnego, że szybko został zajęty przez dzikich lokatorów; według karty budynku wypełnionej przez pracowników BOS 9 sierpnia 1945 r., w 7 izbach zamieszkiwało 30 osób². W lutym 1946 r. gmach przekazano Centralnemu Komitetowi Żydów w Polsce; odbudowę zaś zlecono Państwowemu Przedsiębiorstwu Budowlanemu Kraków I. Kiedy na początku marca robotnicy weszli do gmachu, okazało się, że jest on wciąż zamieszkany, a lokatorzy nic nie wiedzą o planowanych pracach. Na miejscu zjawił się także samozwańczy administrator, który miał grozić wezwaniem milicji ${ }^{4}$. Jak wynika z pism, w budynku zajmowanych było wówczas kilka sal - mieszkało tam osiem rodzin. Sześć z nich wyprowadziło się latem 1946 r. do mieszkań kwaterunkowych, natomiast dwie - rodzina Ratajczyków wraz z sublokatorami (razem 10 osób), zajmująca salę o metrażu 52 metrów kwadratowych ${ }^{5}$, oraz dwuosobowa rodzina Lachów, zajmująca lokal oznaczony jako nr 3 - odmówiły wyprowadzki.

W Archiwum Żydowskiego Instytutu Historycznego, w zespole akt Centralnego Komitetu Żydów w Polsce (Wydział Prawny) zachowała się teczka zawierająca korespondencję w sprawie lokalów na Tłomackiem; możemy z niej odtworzyć

${ }^{1}$ Archiwum Państwowe m.st. Warszawy (dalej APW), Biuro Odbudowy Stolicy (dalej BOS), 72/25/0/-/6972, k. 2.

${ }^{2}$ APW, BOS, 72/25/0/-/6972, Karta budynku z 9 VIII 1945 r., k. 5.

${ }^{3}$ Archiwum Żydowskiego Instytutu Historycznego (dalej AŻIH), Centralny Komitet Żydów w Polsce (dalej CKŻP), Wydział Prawny, 303/XVI/59, Pismo prezydenta m.st. Warszawy do CKŻP, k. 4.

${ }^{4}$ Ibidem, Pismo PPB Kraków I do CKŻP z 8 III 1946 r., k. 7.

${ }^{5}$ Ibidem, k. 10. 
dynamikę sporu. Mniej wiadomo o Ratajczykach i ich współlokatorach; z pisma CKŻP do dyrektora Resortu Mieszkaniowego z 25 października 1946 r. dowiedzieć się można, że Ratajczykowie zgodzili się przyjąć dwa mieszkania jednopokojowe o powierzchni 30 metrów kwadratowych każde, przy ul. Bieniewickiej 46 , i opuścili gmach przy ul. Tłomackie 5. Bardziej skomplikowana okazała się natomiast sprawa Józefa Lacha i jego żony, kategorycznie odmawiających przeprowadzki i stawiających żądania finansowe w postaci „30 kawałków”7. O samym Lachu wiadomo niewiele - jedynie to, że był technikiem zatrudnionym w Zarządzie Miejskim, co mogło być argumentem w sporze o lokal. Sprawę komplikował fakt, że Lach posiadał oficjalny nakaz kwaterunkowy na lokal przy Tłomackiem. Z kolei CKŻP argumentował, że budynek Biblioteki Judaistycznej nigdy nie był przeznaczony na cele mieszkalne. CKŻP, próbując rozwiązać spór, zaproponował Lachowi lokal przy ul. Smulikowskiego 2a, będący dawną pralnią; na wniosek CKŻP zmieniono Lachowi również nakaz kwaterunkowy. Gdy ten jednak dalej nie chciał się wyprowadzić, 12 sierpnia 1946 r. komisyjnie otworzono zajmowany przez niego pokój i w asyście przedstawicieli CKŻP, Wydziału Resortu Mieszkaniowego, urzędnika z Wydziału Mienia Opuszczonego oraz milicjanta wywieziono rzeczy na Smulikowskiego.

Mimo to Lach podjął walkę o powrót na Tłomackie, wysyłając pisma między innymi do prezydenta m.st. Warszawy, Nadzwyczajnej Komisji Mieszkaniowej przy Prezesie Rady Ministrów, Nadzwyczajnej Komisji do Walki z Nadużyciami i Szkodnictwem Gospodarczym, Bolesława Bieruta, prokuratury czy redakcji „Robotnika”. Argumenty Lacha można częściowo zrozumieć: co prawda standard lokalu nr 3 był bardzo niski - pozbawiony był on łazienki, ogrzewania, podłączenia do gazu i ciepłej wody - niemniej w proponowanym mu przez CKŻP jednopokojowym mieszkaniu przy ul. Smulikowskiego 2a, przerobionym z pralni, również tych wygód brakowało. 29 listopada 1946 r. Wydział Kwaterunkowy nakazał CKŻP znalezienie Lachom odpowiedniejszego lokalu9; Centralny Komitet jednak utrzymywał, że mieszkanie przy Smulikowskiego jest odpowiednie; z kolei w piśmie do redakcji „Robotnika” z kwietnia 1947 r. wyjaśniał, że „Centralny Komitet Żydów w Polsce okazał w sprawie Lacha maksimum dobrej woli i nie widzi żadnego powodu, dla którego miałby płacić okup ob. Lachowi”"10. 18 sierpnia 1947 r. Nadzwyczajna Komisja Mieszkaniowa przy Prezesie Rady Ministrów przywraca Lachowi prawo do zajmowania lokalu na Tłomackiem „do czasu otrzymania stosowniejszego mieszkania zastępczego"11. Spotyka się to z kontrofensywą CKŻP, odwołującego się od postanowienia komisji. Tymczasem Lach zawiadamia prokuraturę o kradzieży różnych rzeczy podczas przymusowej wyprowadzki na Smulikowskiego;

${ }^{6}$ Ibidem, Pismo z 25 X 1946 r. do dyrektora Resortu Mieszkaniowego, k. 10.

${ }^{7}$ Ibidem, Pismo CKŻP do dyrektora Wydziału Kwaterunkowego, k. 8.

${ }^{8}$ Lokal ten CKŻP odnajął od adwokata Fiszmana 3 VIII 1946 r., zob. ibidem, Karta budynku z 9 VIII 1945 r., k. 5.

${ }^{9}$ Ibidem, Pismo Wydziału Kwaterunkowego do CKŻP, k. 9.

${ }^{10}$ Ibidem, Pismo CKŻP do redakcji „Robotnika”, k. 18.

${ }^{11}$ Ibidem, Pismo Nadzwyczajnej Komisji Mieszkaniowej do Józefa Lacha/do CKŻP, k. 21. 
postępowanie zostaje umorzone. Sprawa lokalu zostaje skierowana do Wydziału Kwaterunkowego Zarządu m.st. Warszawy, który 14 lutego 1948 r. wydaje orzeczenie utrzymujące nakaz zakwaterowania Lacha przy Smulikowskiego 2a oraz zobowiązujące CKŻP do wykonania niezbędnych napraw. Problem jednak w tym, że Lach nie chce wpuścić ekipy remontowej do mieszkania. Okazuje się również, że na zainstalowanie ubikacji i kuchni musi wyrazić zgodę właścicielka domu, a ta z kolei zgodzić się nie chce. Lach walczy dalej, śląc listy między innymi do ministra administracji publicznej oraz do przewodniczącego Rady Narodowej m.st. Warszawy. Wreszcie wyznacza termin remontu na listopad 1948 r. - tu korespondencja się urywa.

Oprócz niechcianych lokatorów już w pierwszych miesiącach 1947 r. przy Tłomackiem 5 mieszkały osoby zatrudnione przez CKŻP (a później przez ŻIH) do opieki nad budynkiem. Jedną z nich był dozorca Józef Redlisiak, przyjęty do pracy 15 lutego 1947 r., drugą zaś Stefan Gawinek - od 7 stycznia 1947 r. palacz pieca centralnego ogrzewania. Józef Redlisiak pracował w ŻIH aż do przejścia na emeryturę w 1974 r., wypełniając rozmaite obowiązki pracownika administracyjnego: prowadzenie magazynu wydawnictw oraz kasy instytutu, ekspedycję przesyłek pocztowych, załatwianie bieżących spraw w urzędach, odśnieżanie i oczyszczanie terenu wokół budynku itp. Funkcja dozorcy została formalnie usunięta z zakresu jego obowiązków już w 1949 r., niemniej pełnił ją nadal niejako nieoficjalnie w zamian za prawo bezpłatnego zamieszkiwania wraz z żoną i dwójką dzieci w budynku². Na tej samej zasadzie przy Tłomackiem mieszkał Stefan Gawinek razem z żoną Zofią i czwórką dzieci. Po jego śmierci w 1959 r. Zofia Gawinek została zatrudniona w ŻIH jako woźna i sprzątaczka, z zachowaniem prawa do mieszkania ${ }^{13}$.

Lokale zajmowane przez rodziny Redlisiaków i Gawinków mieściły się w suterenie budynku i prawdopodobnie były tymi samymi lokalami, które wcześniej zajmowali dzicy lokatorzy. Trudno stwierdzić, czy z biegiem czasu to dyrekcja ŻIH chciała zagospodarować suterenę na magazyny archiwalne, czy też jej mieszkańcy dążyli do uzyskania lepszych mieszkań. Niemniej na przełomie 1964 i 1965 r. obie rodziny opuściły ŻIH, uzyskawszy mieszkania komunalne, zresztą dzięki pomocy finansowej Towarzystwa Społeczno-Kulturalnego Żydów za pośrednictwem Ż̇H ${ }^{14}$.

Jak się wkrótce okazało, pozbycie się stałych lokatorów miało nieoczekiwaną dla dyrekcji ŻIH konsekwencję. Budynek ŻIH wraz z bezcennymi zbiorami archiwalnymi, muzealnymi i bibliotecznymi pozostał całkowicie bez ochrony w godzinach od 16 do 8 rano. Ponadto od początku roku 1965 w związku z wejściem w życie ustawy zabraniającej ubezpieczania w PZU instytucji utrzymywanych

${ }^{12}$ AŻIH, Żydowski Instytut Historyczny (dalej ŻIH), Dział Kadr, 12A, Teczka personalna Józefa Redlisiaka, k. 42, 75, 76.

${ }^{13}$ Ibidem, 35, Teczka personalna Stefana Gawinka, k. 2-5, 8; ibidem, 65, Teczka personalna Zofii Gawinek, k. 12-15.

${ }^{14}$ AŻIH, ŻIH, Korespondencja, L.dz. 1363/64, Pismo dyrektora Bernarda Marka do Centralnej Żydowskiej Komisji Społecznej przy TSKŻ z 7 XI 1964 r. 
z budżetu państwa wymienione zbiory nie były w żaden sposób ubezpieczone ${ }^{15}$. W ciągu następnych miesięcy trwały gorączkowe próby rozwiązania tej sytuacji między innymi przez zatrudnienie Redlisiaka na umowę zlecenie, co okazało się trudne z uwagi na niemożność połączenia pracy w dzień i w nocy ${ }^{16}$. Z akt personalnych wynika, że mimo to Redlisiak pracował jako nocny dozorca aż do października 1966 r., gdy do ochrony budynku wynajęto Spółdzielnię Dozoru Mienia „Uniwersum”17.

\section{Pismo PPB Kraków I do CKŻP 18}

Państwowe Przedsiębiorstwo Budowlane

Warszawa, dn. 5 marca 1946

Kraków I

Oddział Warszawski - Warszawa - Polna 36.

Do

Centralnego Komitetu Żydów Polskich W-wa, ul. Szeroka 5

W dniu 2 marca odbyła się komisyjna lustracja gmachu Biblioteki Judaistycznej przy ul. Tłomackie 5, przy czym stwierdzono, że część pomieszczeń gmachu jest zajęta przez przygodnych lokatorów, którzy wprowadzili się tam wraz z rodzinami i ruchomościami, przy czym część zajętych pomieszczeń była zamknięta na założone kłódki.

Dopóki powyższy stan rzeczy nie ulegnie całkowitej likwidacji, nie może być mowy o normalnym zorganizowaniu i poprowadzeniu robót budowlanych.

Wobec powyższego, mając na uwadze krótki termin dany nam na zakończenieodbudowy, prosimy o jak najszybsze wyeksmitowanie wszystkich bez wyjątku lokatorów i umożliwienie nam zamknięcia i zabezpieczenia wejść do gmachu, w którym złożone będą nasze materiały budowlane.

/-/ stempel

/-/ inż. R. Roszkowski

Źródło: AŻIH, CKŻP, Wydział Prawny, 303/XVI/59, k. 6.

${ }^{15}$ Ibidem, L. dz. 792/65, Pismo dyrektora Bernarda Marka do sekretarza naukowego I Wydziału PAN z 25 V 1965 r.

${ }^{16}$ Ibidem, Pismo sekretarza naukowego I Wydziału PAN do Bernarda Marka z 14 VI 1965 r.

${ }^{17}$ AŻ̇H, ŻIH, Dział Kadr, 12A, Teczka personalna Józefa Redlisiaka, k. 72.

${ }^{18} \mathrm{~W}$ dokumentach - poza pismami Józefa Lacha - uwspółcześniono ortografię i interpunkcję. 


\section{Pismo CKŻP do dyrektora Wydziału Kwaterunkowego}

Centralny Komitet Żydów Polskich

Warszawa, ul. Sienna 60
Warszawa, dnia 30 września 1946 r.

Do

Ob. Dyrektora Wydziału Kwaterunkowego w Warszawie

W domu przysynagogalnym przy ul. Tłomackie nr 5 mieściła się przed wojną przysynagogalna biblioteka judaistyczna. Zarząd synagogi z tym przeznaczeniem wybudował ten dom. Decyzją Prezesa [Rady] Ministrów, Komisji Trzech oraz Prezydenta m.st. Warszawy dom ten zgodnie z pierwotnym jego przeznaczeniem i charakterem został przekazany Centralnemu Komitetowi Żydów Polskich.

6 lokatorów tego domu, rozumiejąc, że dom nie był i nie jest mieszkalnym, że stanowi składową część synagogi i przeznaczony jest jak dawniej na zaspokajanie potrzeb kulturalno-oświatowych i religijnych ludności żydowskiej - dobrowolnie opuściło zajmowane pomieszczenie, umożliwiając przeprowadzenie remontu.

Natomiast 2-ch lokatorów (Lach i Ratajczyk) od samego początku pragnęło wykorzystać przymusowo sytuację i wymusić bezprawnie od Centralnego Komitetu Żydów Polskich jak najwięcej pieniędzy.

Przedstawiciele CKŻP niejednokrotnie zwracali się zarówno do Lacha, jak i Ratajczyka (w okresie, gdy wystaranie się o inne mieszkanie było znacznie łatwiejsze - maj, czerwiec, lipiec) z prośbą o dobrowolne opuszczenie zajmowanych przez nich pomieszczeń, wyrażając w tym wypadku gotowość pokrycia pełnych kosztów przeprowadzki oraz dokonanych remontów i napraw. Ob. Lach zażądał pierwotnie „30 kawałków”, miał się zgłosić do dalszych rokowań, lecz widocznie się rozmyślił, sądząc zapewne (jak się sam wobec sąsiadów wyraził), że „Żydzi mają dużo pieniędzy i zapłacą nam tyle, ile chcemy”.

Od wszelkich dalszych rokowań pomimo nalegań ob. Lach się uchylił, celowo tamując remont budynku społecznego. Złośliwość ob. Lacha była tem widoczniejsza, że zajmowane przezeń pomieszczenie było ogromnie zniszczone, tynki częściowo odpadły, podłogi zniszczone, pokój, jako niezamieszkalny, nie posiadał przewodu kominowego (wobec czego rura od ustawionego $\mathrm{w}$ pomieszczeniu piecyka wyprowadzona była przez szybę na ulicę), nie ma przewodu wodnego ani zlewu. Znalezienie innego pomieszczenia i to bardziej ludzkiego nie nastręczało ob. Lachowi żadnych trudności, zwłaszcza że poza żoną nikt z nim nie mieszkał.

Opór jego w świetle powyższego daje się uzasadnić jedynie antyspołecznym nastawieniem i chęcią bezprawnego wzbogacenia się na cudzy rachunek. Okoliczności powyższe znalazły całkowite potwierdzenie w zebranym dotychczas materiale i w zeznaniach świadków.

W tych warunkach CKŻP prosił o przekwaterowanie ob. Lacha do lokalu nr 16 przy Smulikowskiego nr 2, który to lokal jest znacznie odpowiedniejszy od 
uprzednio zajmowanego, co zresztą także zostało stwierdzone przez kontrolera Wydziału Kwaterunkowego.

Jeżeli Lach w chwili obecnej założył sprzeciw przeciwko przekwaterowaniu, to nie dlatego, że otrzymał lokal rzekomo gorszy (sam zresztą przyznał wobec administratora CKŻP, że jest to pokój możliwy), ale tylko dlatego, że wymknęła mu się okazja do uzyskania bezprawnej korzyści materialnej.

Żądania ob. Lacha są całkowicie bezpodstawne. Prosimy o całkowite ich odrzucenie. Jest rzeczą oczywistą, że w przysynagogalnym budynku przeznaczonym na spełnianie potrzeb kulturalno-oświatowych i religijnych i w tym charakterze przekazanym Centralnemu Komitetowi [Żydów w Polsce], ni e ma p o m i e s zczeń mieszkalnych; zajmowane zaś obecnie przez ob. Ratajczyka równi eż wi nno być o p różnion e $\mathrm{e}^{19}$.

Równocześnie CKŻP prosi o rozważenie możliwości skierowania sprawy p[rzeciw]ko Lachowi do Komisji Specjalnej o celowe szkodnictwo społeczne.

/-/ M. Zojszajn, Członek Prezydium²0

/-/ M. Bitter, [Wicep]rzewodniczący ${ }^{21}$

Źródło: AŻIH, CKŻP, Wydział Prawny, 303/XVI/59, k. 8.

\section{Pismo CKŻP do Nadzwyczajnej Komisji Mieszkaniowej}

Centralny Komitet Żydów w Polsce

Warszawa, dnia 13 września 1947 r.

Warszawa, ul. Sienna 60

Nr Spr. 2548/47

Do

Nadzwyczajnej Komisji Mieszkaniowej

Przy Prezesie Rady Ministrów

w Warszawie

Dom posynagogalny - Biblioteka Judaistyczna - przy ul. Tłomackie nr 5 w Warszawie został wielomilionowym kosztem odbudowany w r. 1946 przez Centralny

\footnotetext{
${ }^{19}$ Dopisek odręczny.

${ }^{20}$ Mordechaj Zonszajn (1906-?) - syjonista, działacz partii Ichud, skarbnik CKŻP. August Grabski, Działalność komunistów wśród Żydów w Polsce (1944-1949), Warszawa: Trio, 2004, s. 106, 147; AŻIH, CKŻP, Wydział Personalny, 303/III/20, k. 33.

${ }^{21}$ Marek Bitter ([1902?]1903-1965) - robotnik, członek Komunistycznej Partii Polski od 1928 r., w czasie wojny w getcie warszawskim, partyzant na Zamojszczyźnie. Wiceprzewodniczący CKŻP od 1945 r., działacz Frakcji PPR, pracował również w Centralnej Żydowskiej Komisji Historycznej. W latach 1951-1956 w Ministerstwie Przemysłu Ciężkiego, później w Zakładach Elektronicznych im. F. Zubrzyckiego w Warszawie. Grabski, Działalność komunistów..., s. 68; AŻIH, CKŻP, Wydział Personalny, 303/III/20, k. 31.
} 
Komitet Żydów w Polsce i przeznaczony na potrzeby Centralnej Żydowskiej Komisji Historycznej w Polsce.

W zniszczonym przez okupanta budynku zamieszkało w r. 1945 kilkanaście rodzin. Na skutek porozumienia się z nimi Centralny Komitet Żydów w Polsce, jakkolwiek nie miał obowiązku, odnalazł im odnośne lokale i wszyscy dobrowolnie opuścili lokale, prócz ob. Lacha, który oświadczył, że on od Żydów wyciągnie maximum.

W tych warunkach Centralny Komitet Żydów w Polsce postarał się w r. 1946 o lokal zastępczy na ul. Smulikowskiego, dokąd ob. Lach został przeniesiony.

W domu Tłomackie 5 nigdy lokali mieszkalnych nie było. Dawny gmach Wielkiej Biblioteki Judaistycznej mieści obecnie Archiwum, Bibliotekę i Biura Centralnej Żydowskiej Komisji Historycznej w Polsce.

W tych warunkach wydaje się nam, że postanowienie Nadzwyczajnej Komisji Mieszkaniowej przy prezesie Rady Ministrów w sprawie nr 2548/47, przyznając jakiekolwiek prawa ob. Lachowi do sali nr $3 \mathrm{w}$ domu nr 5 przy ul. Tłomackie w Warszawie, w której mieszczą się urządzenia archiwalne i dokumenty o bezcennej wartości, utrzymać się nie może, wobec czego Centralny Komitet Żydów w Polsce prosi o wznowienie postępowania i reasumpcję wzmiankowanego postanowienia.

/-/ P. Zelicki, Generalny Sekretarz ${ }^{22}$

/-/ M. Bitter, [Wicep]rzewodniczący

Źródto: AŻIH, CKŻP, Wydziat Prawny, 303/XVI/59, k. 22.

\section{Pismo Józefa Lacha do CKŻP}

Lach Józef

Warszawa, dnia 1 grudnia 1947 r.

ul. Tłomackie nr 5 m. 3

obecnie Smulikowskiego nr 2a pralnia dom.

Do Ob. Prezesa

Centralnego Komitetu Żydów Polskich w miejscu

Z uwagi na to, że końcem m. lipca $1946 \mathrm{r}$. w godzinach południowych mec. Ołomucki²3 ${ }^{23}$ czł[onek] Centr[alnego] Komit[etu] Żyd[ów] [w] Pol[sce] przybył do

${ }^{22}$ Paweł Zelicki (1901-?) - cholewkarz i buchalter, przed wojną działacz Bundu, a w latach 1926-1928 KPP w Radomiu, później Międzynarodowej Organizacji Pomocy Rewolucjonistom (MOPR). W czasie wojny przebywał w ZSRR. Po wojnie członek PPR i sekretarz CKŻP, od 1946 r. przewodniczący Centrali Spółdzielni Wytwórczych „Solidarność”. Po 1956 r. wyjechał do Izraela, wstąpił do partii Mapai. Grabski, Działalność komunistów..., s. 68.

${ }^{23}$ Aleksander Ołomucki (1902-1976) - adwokat, założyciel i kierownik zespołu adwokackiego nr $6 \mathrm{w}$ Warszawie. Zatrudniony w Wydziale Prawnym CKŻP jako radca. AŻIH, CKŻP, Wydział Personalny, 303/III/19, k. 14; ibidem, Wydział Prawny, 303/XVI/21, k. 1. 
mego lokalu z propozycją przyjęcia sumy zł 15-25 tysięcy za opróżnienie lokalu przeze mnie zamieszkałego [sic!], czemu ja, opierając się na art. 12. p. 1. poz. 27. Dekretu z dnia 22.12.[19]45²4 odmówiłem, godząc się jednak na lokal zamienny.

Dnia 12.8.1946 r. administrator CKŻP ob. Święcki ${ }^{25} \mathrm{w}$ asyście milicjanta nr 751, uzbrojonego, dokonał włamania drzwi do mego lokalu w czasie mojej nieobecności, skąd przy pomocy dobranych sobie ludzi usunął z mieszkania rzeczy moje na korzyść CKŻP, lokując je w pralni domu nr 2a ul. Smulikowskiego w Warszawie wbrew postanowieniom art. art. 18 ust. 1. i 2. oraz 32. ust. 1., 2. i 3., a także art. art. 33., 36. i 37. ${ }^{26}$, a narażając mnie tym sposobem na straty spowodowane zaginięciem niektórych przedmiotów, ogólnej wartości 24810 zł, a mianowicie:

Zegarek kieszonkowy „Omega” bez szkiełka

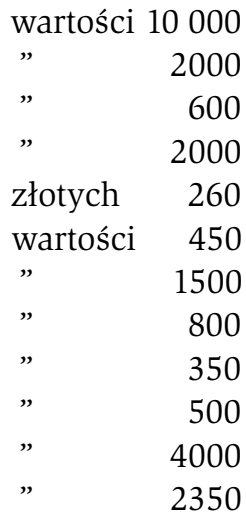

Suwak logarytmiczny „Ritza”

Wizerunek Chrystusa

Obraz olejny, kopia Rapackiego „Zima”

2000

Gotówka

Tarka, stolnica kuchenna, 2 talerze stłuczone

Drzwi szpuntowe używane

Pion i skalówka techniczna

Scyzoryk kieszonkowy

350

Mapa Europy wschodniej i zachodn.

500

Plan budowy domu mieszkalnego o kubaturze $\mathrm{m}^{3} 76$

Komplet cyrkli techn.

2350

Z przyczyn powyższych uprzejmie proszę o zwrot pow[yższych] strat w terminie do dnia 15 grudnia 1947 r., w przeciwnym razie zmuszony będę skierować sprawę na drogę sądową.

[dopisek odręczny]

Z poważaniem

[Józef Lach]

Nadmieniam, że straty nie obejmują przedmiotów w piwnicy, która pozostaje dotychczas przy ul. Tłomackie nr 5 i jest zamkniętą na moją kłódkę.

Źródto: AŻIH, CKŻP, Wydziat Prawny, 303/XVI/59, k. 23.

${ }^{24}$ Dekret z 21 XII 1945 r. o publicznej gospodarce lokalami i kontroli najmu. Artykuł 12 p. 1 brzmiał: „Zabronione i nieważne są umowy o odstępne w jakiekolwiek postaci na rzecz ustępującego najemcy (podnajemcy) lub właściciela nieruchomości bądź na rzecz innej osoby, jak również o wynagrodzenie za pośrednictwo przy najmie i wyszukaniu lokalu lub o świadczenia, niepozostające w bezpośrednim związku z najmem (podnajmem)”.

${ }^{25}$ Jerzy Święcki. W dokumentach publikowanych dalej figuruje jako kierownik Sekcji Nieruchomości CKŻP, niemniej jego akta personalne nie zachowały się w zespole CKŻP w AŻIH.

${ }^{26}$ Lach powołuje się tu na przepisy dekretu z 21 XII 1945 r., dotyczące lokali zastępczych, kosztów przeprowadzki, wysłuchania przez komisję kwaterunkową osób zainteresowanych, wydawania decyzji na piśmie, prawa do odwołania się od decyzji oraz przymusowego usunięcia. 


\section{Pismo Wydziału Gospodarczego CKŻP do Wydziału Prawnego}

Wydział Gospodarczy CKŻP

Sekcja Nieruch[omości]
Warszawa, dn. 12 XII 1947 r.

Do

Wydziału Prawnego przy CKŻ w P[olsce]

W związku z pismem ob. Lacha w sprawie odszkodowania wyjaśniam, co następuje.

Przekwaterowanie ob. Lacha z lokalu nr $3 \mathrm{w}$ gmachu ul. Tłomackie 5 dokonał z polecenia Resortu Mieszkaniowego urzędnik tego Resortu w asyście urzędnika Wydziału Mienia Opuszczonego oraz przedstawiciela 7. kom[isariatu] MO. Urzędnik Wydziału mienia opuszczonego w obecności ww. dokładnie spisał wszystkie ruchomości, które znajdowały się na miejscu, drobne rzeczy zostały umieszczone w małej szafce, która została opieczętowana, pieczęciami również zostały obłożone inne przedmioty oraz szafa, rzeczy te zostały przewiezione do lokalu przy ul. Smulikowskiego 2a i tam zostały doręczone obywatelce Lach, która się tam zgłosiła. Przy wszystkich tych czynnościach obecni byli wszyscy wyżej wymienieni.

W powyższej sprawie zostałem przesłuchany przez Władze Śledcze na skutek skargi Lacha do prokuratora, gdzie ob. Lach podał sumę zaginionych rzeczy 1300 [zł], a nie jak obecnie 24810 [zł]. Sprawa została umorzona przez Prokuratora Sądu Grodzkiego w Warszawie nr akt III Dz 661/46. [...]

/-/ Jerzy Święcki, Kierownik Sekcji Nieruchomości przy CKŻP27

Źródto: AŻIH, CKŻP, Wydział Prawny, 303/XVI/59, k. 24.

\section{Orzeczenie Wydziału Kwaterunkowego Zarządu m.st. Warszawy z dnia 14 lutego $1948 \mathrm{r}$.}

Dnia 31 stycznia 1948 r./14 lutego 1948 r. Miejska Komisja Lokalowa w składzie: Przewodniczący W. Rudka

Członkowie: Sokołowski, Wysocki

Przy udziale protokolanta St. Morawskiej

po rozpoznaniu sprawy Józefa Lacha przeciwko Centralnemu Komitetowi Żydów [w] P[olsce]

orzeka:

nakaz przekwaterowania Józefa Lacha z lokalu nr 3 przy ul. Tłomackie nr 5 do lokalu nr 16 przy ul. Smulikowskiego 2a utrzymać w mocy

${ }^{27}$ W zespole CKŻP w AŻIH nie zachowały się akta Sekcji Nieruchomości - być może istniała ona bardzo krótko. Rewindykacją nieruchomości należących do przedwojennych organizacji żydowskich oraz ich zagospodarowaniem na potrzeby CKŻP zajmował się Wydział Prawny CKŻP. Zob. Tadeusz Epsztein, „Inwentarz Archiwum Wydziału Prawnego CKŻP 1945-1950”, mps w AŻIH, Warszawa 2010, s. 3. 
zobowiązać Centralny Komitet Żydów w Polsce do wykonania w terminie 30 dni od daty wydania wymienionych napraw i remontów w lokalu przy ul. Smulikowskiego 2a m. 16:

położenie podłogi drewnianej

zainstalowanie ubikacji i kuchni

pomalowanie ścian wewnętrznych

usunięcie i zamurowanie otworów na strych

usunięcie ścieków (pozostałość po pralni)

dostarczenie piwnicy

[podpisy]

Źródto: AŻIH, CKŻP, Wydział Prawny, 303/XVI/59, k. 35.

\title{
Skarga Józefa Lacha
}

Lach Józef technik Zarz[ądu] Miej[skiego]

Warszawa, dnia 18 maja $1948 \mathrm{r}$. Zam. ul. Smulikowskiego nr 2a

w Warszawie

\author{
Do \\ Ob. Ministra Administracji Publicznej \\ Rzeczyp[ospolitej] Polskiej
}

\section{Skarga}

Z uwagi na pogwałcenie Ustaw i Dekretu Państwa Polskiego - uprzejmie proszę o niezwłoczną interwencję, a mianowicie:

Działo się dnia 12.8.1946 r.: adm[inistrator] CKŻP ob. Święcki Jerzy w tow[arzystwie] milicjanta nr 751 i ob. Kolasińskiego, prac[ownika] W[ydzia]łu Kwaterunkowego m.st. W[arsza]wy w czasie mojej nieobecności - dokonał włamania drzwi mieszkania nr 3 przy ul. Tłomackie $5 \mathrm{w}$ Warszawie - skąd przemocą usunął rzeczy moje, lokując je w pralni domowej ul. Smulikowskiego nr. 2a 4-ego piętra bez kuchni, podłogi (bet[onowa?]), o dziurawych ścianach $\mathrm{z}$ otworem na dach i bez klozetu (ogóln[ie?] brak), powodując zaginięcie wiele przedmiotów domowego użytku oraz narzędzi pracy, a tym samym pozbawiono mnie wraz z chorą żoną z Powstania Warszawskiego (Starówki) należnego odpoczynku po pracy i dalszej pracy w godzinach nadlicz[bowych].

Z przyczyn powyższych, że ob. Święcki Jerzy przy pomocy gwałtu wszedł w posiadanie mego lokalu na korzyść Centralnego Komitetu Żydów w Polsce, mimo iż posiadam nakaz kwaterunkowy nr 10689/45, wniosłem skargi do:

1. Nadzwyczajnej Komisji Walki z Nadużyciami

2. Nadzwyczajnej Komisji Mieszkaniowej Przy Prezesie Rady Ministrów

3. Nadzwyczajnej Komisji Mieszkaniowej m.st. Warszawy

4. Wydziału Kwaterunkowego

5. Prezydenta Miasta St. Warszawy 
6. Szefa Resortu Mieszkaniowego m.st. Warszawy

7. Komisji Lokalowej Miejskiej m.st. Warszawy

Wszystkie wyż[ej] wym[ienione] instytucje wprawdzie wypowiadają się na moją korzyść, to jednak jak z załączników wynika, brak im organu wykonawczego, co pozwala mi przypuszczać, iż nie są tworem prawnym, lecz tylko humanitarnym. Obywatelu Ministerze! [sic!]

Ponieważ czyn popełniony jest sprzeczny z art. art. 18., 32., 33., 36., 37 1a. Dekretu 27 o publicznej gospodarce lokalami i kontroli najm[u] z dn. 21.12.1945, a tymczasowym podpada art. art. 26., 251., 252., 257. i 262. Kodeksu Karnego ${ }^{28}$ uprzejmie proszę o zajęcie odpowiedniego stanowiska resortowego.

Z socjalistycznym pozdrowieniem

/-/ J. Lach

Źródło: AŻIH, CKŻP, Wydziat Prawny, 303/XVI/59, k. 32.

\section{Pismo CKŻP do ministra administracji publicznej z 9 czerwca 1948 r.}

W odpowiedzi na pismo Ob. Dyrektora z dn. 22 V. [19]48 l.dz. Z.88/T/48, uprzejmie komunikujemy, że sprawa ob. Lacha była przedmiotem wielokrotnych rozważań CKŻwP.

Okoliczność ta tłumaczy się między innymi tym, że spis Urzędów i Władz, podany w skardze przez petenta, którym należało udzielić odpowiedzi i wyjaśnień, nie jest pełny, gdyż ob. Lach zapomniał wspomnieć o skargach do ob. Prezydenta Rzeczypospolitej, do ob. Prezesa Rady Ministrów, do Prokuratora Sądu Okręgowego w Warszawie, redakcji „Robotnika” itp.

Odpowiada prawdzie, że ob. Józef Lach został przekwaterowany z wypalonej izby przy ul. Tłomackie 5 (dom Biblioteki Judaistycznej, obecnie Instytutu Historycznego) do dużego, widnego pokoju na 4-tym piętrze przy Smulikowskiego 2a, po uprzednim wydaniu decyzji przez Wydział Kwaterunkowy Zarządu Miejskiego. Prawdą jest również, że w chwili przybycia przedstawicieli Władz Kwaterunkowych w asyście milicji w sprawie przekwaterowania ob. Lacha do lokalu zastępczego przy ul. Smulikowskiego 2a, skarżącego, mimo że o czynności przekwaterowania był na piśmie uprzednio powiadomiony - w domu nie było. Ta celowa nieobecność nie mogła, rzecz oczywista, wstrzymać czynności urzędowych, a twierdzenie, jakoby funkcjonariusz CKŻwP dokonał włamania do pokoju ob. Lacha i przemocą usunął ruchomości - jest zmyślone.

Pragniemy zauważyć, że w nieruchomości Biblioteki Judaistycznej zamieszkiwało w r. 1946 kilkadziesiąt osób. Ze wszystkimi Centralny Komitet Żydów w Polsce

${ }^{28}$ Lach powołuje się tu na tzw. kodeks Makarewicza z 1932 r., a dokładniej na przepisy dotyczące przywłaszczania mienia, wdzierania się do cudzego lokalu oraz podżegania do popełnienia przestępstwa (art. 26) i zmuszania „przemocą lub groźbą bezprawną innej osoby do działania” (art. 251). 
załatwił sprawę przeniesienia się polubownie i bez jakiegokolwiek zatargu. Jedynie ob. Lach utrzymywał, że Żydzi, którym tak bardzo zależy na uruchomieniu Instytutu Historycznego właśnie w gmachu dawnej Biblioteki Judaistycznej, zapłacą tyle, ile on zechce. Ew[entualnie] godził się ob. Lach na dostarczenie mu przez CKŻwP w zamian wypalonego pokoju bez wygód, ubikacji, wody, światła, bez kuchni i nawet przewodu kominowego przy ul. Tłomackie 5 (dom ten budowany był na biura, a nie na mieszkania prywatne) 2-izbowego lokalu z wygodami na ul. Marszałkowskiej.

Temu żądaniu zadośćuczynić nie mogliśmy i nie chcieliśmy [...].

Źródto: AŻIH, CKŻP, Wydziat Prawny, 303/XVI/59, k. 41.

\section{Pismo Przewodniczącego Rady Narodowej m.st. Warszawy Stanisława Sankowskiego do CKŻP z 21 sierpnia 1948 r.}

Orzeczeniem Miejskiej Komisji Lokalowej z dnia 31 I 1948 CKŻP został zobowiązany do wykonania remontów, wymienionych w tym orzeczeniu w lokalu nr 16 przy ul. Smulikowskiego 2a, zajmowanym przez Józefa Lacha. [...] Udzielony przez M[iejską K[omisję] L[okalową] termin miesięczny do wykonania zakreślonych robót upłynął i żadne naprawy nie zostały przez CKŻP dokonane.

Ob. Lach czuje się pokrzywdzonym bezwzględnym stanowiskiem CKŻP i odwołuje się do różnych instancji [...]. Ze względu na specyficzny charakter sprawy, ciężkie warunki mieszkaniowe i materialne ob. Lacha oraz znaną postawę moralną CKŻP uważam, że celowym byłoby zlikwidowanie tego zbyt głośnego i niepożądanego sporu przez dokonanie w lokalu napraw, wymienionych w orzeczeniu, jako niezbędnych dla egzystencji człowieka pracy.

Opinię swą opieram w obecnym stadium sprawy nie na formalnych przepisach prawa, a na życiowym, ludzkim podejściu do sprawy, co uważam za istotne przy likwidowaniu tego rodzaju zatargów [...].

Źródto: AŻIH, CKŻP, Wydział Prawny, 303/XVI/59, k. 42.

\section{Odpowiedź CKŻP z 6 września 1948 r. na pismo przewodniczącego Rady Narodowej}

[...] Wyrażamy gotowość wykonania w terminie do 15 października 1948 roku następujących napraw [...]:

1. położenia podłogi drewnianej

2. pomalowania ścian wewnętrznych

3. usunięcie i zamurowanie otworów na strych

4. usunięcie ścieków (pozostałość po pralni)

Co się tyczy zainstalowania ubikacji i kuchni, to roboty powyższe wymagają uprzedniego zezwolenia miejskich władz inspekcji budowlanej i wodociagowo- 
-kanalizacyjnych oraz zgody właścicieli nieruchomości. [...] Natomiast dostarczyć piwnicy nie jesteśmy w stanie, gdyż jest to tylko w dyspozycji administracji nieruchomości, a poza zasięgiem naszych możliwości.

Dziękujemy za wyrazy uznania dla moralnej postawy CKŻwP i ze swej strony podkreślić musimy, że pragnęliśmy podejść do sprawy w sposób życiowy i ludzki, a przedłużenie się sporu z ob. Lachem nastąpiło nie z naszej winy.

/-/ Julian Łazebnik, Generalny Sekretarz ${ }^{29}$

/-/ Salo Fiszgrund, [Wicep]rzewodniczący ${ }^{30}$

Źródto: AŻ̇H, CKŻP, Wydział Prawny, 303/XVI/59, k. 43.

\title{
Słowa kluczowe
}

Tłomackie 3/5, Żydowski Instytut Historyczny, Centralny Komitet Żydów w Polsce (CKŻP), dzicy lokatorzy

\begin{abstract}
In 1945 the building of the Central Judaist Library was inhabited by ca. 30 illegal tenants. After the real estate had been taken over in February 1946 by the Central Commission of Polish Jews most of them moved, but one family refused to leave the apartment they had been living in. Certain files that have survived in the Legal Department of the Archive of the Jewish Historical Institute contain correspondence regarding the rooms on Tłomackie Street, which allow for a reconstruction of the dispute that began in 1948 and which this article describes. Aside from the profiles of the illegal tenants we also present the profiles of the legal tenants of the building at Tłomackie Street No. 5.
\end{abstract}

\section{Key words}

Tłomackie Street No 3/5, Jewish Historical Institute (Żydowski Instytut Historyczny, ŻIH), the Central Commission of Polish Jews (Centralny Komitet Żydów w Polsce, CKŻP), illegal tenants

${ }^{29}$ Julian Łazebnik (1904-1981) - od 1921 r. działacz Związku Młodzieży Komunistycznej w Warszawie, członek KPP, organizował strajk tramwajarzy w 1931 r., kilkakrotnie aresztowany. Walczył w kampanii wrześniowej, uciekł z obozu dla internowanych do ZSRR, kierował kołem Związku Patriotów Polskich w Taszkiencie. Wrócił do Polski we wrześniu 1946 r., został członkiem PPR i sekretarzem generalnym CKŻP. Od 1950 r. był członkiem zarządu głównego Towarzystwa Społeczno-Kulturalnego Żydów w Polsce i pracował jako cenzor. Zob. Grabski, Działalność komunistów..., s. 308.

${ }^{30}$ Salo (Salomon) Fiszgrund (1893-1971) - polityk, w okresie międzywojennym sekretarz komitetu Bundu w Krakowie i działacz Kultur-Ligi (organizacji krzewiącej kulturę jidysz). W czasie wojny w getcie warszawskim, następnie ukrywał się po tzw. aryjskiej stronie, działał w konspiracyjnym Bundzie. Po wojnie był wiceprzewodniczącym CKŻP, a w latach 1945-1949 sekretarzem generalnym CK Bundu. Wyemigrował po 1968 r. do Izraela. Zob. August Grabski, Żydowski ruch kombatancki w Polsce w latach 1944-1949, Warszawa: Trio, 2002, s. 180. 